I have this evening in a humble way been endeavouring to pay tribute to Rumford and Joule and other great scientists. The Battersea Power Station pays tribute to Faraday in a manner which justifies me in regarding the modern engineer as one who fully appreciates the work of his brother engineer who concerns himself with the minute electrical machines of Nature which the eye eannot even see.

This is a copy of the inscription on the Foundation Stone of the Station:

\section{THE LONDON POWER COMPANY, LMMTED} ON ST. GEORGE'S DAY

IN THE YEAR QF THE CENTENARY OF MICHAEL FARADAY'S GREAT DISCOVERY

THIS STONE OF COMMEMORATION

UNVEILED AT A MOMENT ABOUT NOON AND BX A

WIRELESS MESSAGE FROM OTTAWA BY

HIS EXCELLENCY THE GOVERNOR-GENERAL OF CANADA THE RIGHT HONOURABLE THE EARL OF BESSBOROUGH, G.C.M.G.

A FORMER DIRECTOR OF THE COMPANY

WAS PLACED AS A LANDMARK IN THE DEVELOPMENT OF IAARGER LONDON'S LIGHT AND POWER AND TO SERVE AS ANOTHER MEMORIAL OF THE SCIENTIFIC HERITAGE DERIVED FROM FAMOUS ENGLISHMEN

BATTERSEA POWER STATION 23RD APRIL 1931.

In the engine room, which looks like the nave of a modern cathedral, there are at present two steam turbines with an output of 120,000 kilowatts and soon there will be a third, making a total output of 220,000 kilowatts or nearly 300,000 horse power. When I visited the Station I saw very few engineers and technicians. There was only one in the main engine-room, and he wore a spotless white coat. The 100 tons of coal which the furnaces consume every hour had never once been man-handled from the moment the mechanical grabs lifted 5 tons of it at a time from the ships alongside the wharves, until the time at which the remnants were finally removed as ash. The stoker aisle, as long as an average street, was absolutely deserted. The toiling, half-naked stoker, shovelling coal into white-hot furnaces, has no place at Battersea. Instead I saw one man controlling the six furnaces in action from a desk panel in accordance with instructions from the combustion engineers' office high up in the building. In that office the pressure, temperature and everything it is necessary to know about the steam-generating plant can be obtained from distant recording instruments and recorders by the twist of a knob. In this way, two or three men control the firing and generation of steam raising equipment, each of the six units of which generates a quarter of a million pounds of steam an hour at a pressure of $650 \mathrm{lbs}$. per square inch. What goes out of the chimneys is steam and not smoke; it is the steam of the water used in cleaning the smoke in the flues. The gases from the furnaces are driven by fans into washers in which they are sprayed with water so that 20 per cent of the sulphur is removed. They then pass into the scrubbers proper which are arranged in the main flue between the two chimneys where, by the action of moist iron filings, a further 70-75 per cent of the sulphur is removed. Further on, the gases are treated with an alkaline solution and finally passed through moisture eliminators. The wash water used to purify the gases passes away through aerating tanks and filter beds outside the Station for purification before return to the river. With its three great steam turbines the horse power available will be greater than that of the 10,000 steam engines which were reckoned to be in Great Britain at the beginning of last century, a power superior according to Stuart to that of four and a half millions of labourers.

Here, indeed, is a fine example of the engineer's service to man.

(To be continued.)

\title{
The Museum of Practical Geology
}

$\mathrm{I}^{\mathrm{N}}$ his report for the year 1933*, the Director of the Geological Survey and Museum of Practical Geology has included a short history of the Museum from its inception to the present day. The occasion was appropriate, for at the end of that year the Museum finally closed its door to the public, thereby placing one more milestone on the road of development of a characteristically British institution.

The prime cause of the Museum's foundation was the private geological mapping undertaken by De la Beche in Cornwall and Devon by arrangement with the Board of Ordnance. Four sheets of the Devon 1-in. map, geologically coloured, were published in 1834. In 1835 the Board of Ordnance

* Report of the Geological Survey of Great Britain and the Museum of Practical Geology (Summary of Progress) for the Year 1933, Part 1. H.M. Stationery Office. Price 1s. 6d. net. decided to establish a department to deal with the geological colouring of its maps. It was known as the Ordnance Geological Survey, De la Beche was put in charge, and the Treasury allotted $£ 300$ a year for its upkeep. By this time, however, so much material had been collected by De la Beche that he was compelled to ask for suitable housing for it, and in 1837, Woods and Forests provided accommodation in a house in Craig's Court, Charing Cross; by 1839 the collections were in a fair state of order. In the same year a small laboratory was installed for the analysis of rocks, minerals and soils, with $R$. Phillips, the curator, as chemist. In 1838 , T. Sopwith, with the support of De la Beche, had read a paper before the Newcastle meeting of the British Association, on the need for the conservation of mining records ; this, the Association backed by a resolution which 
resulted in the establishment of the Mining Record Office at Craig's Court.

De la Beche's great conception of an organisation uniting with the Geological Survey, the Museum of Economic Geology (as it was then called), and the Mining Record Office, a School of Mines having teaching equipment to cover, besides mining and metallurgy, all the related sciences required for a knowledge of mineral products and their uses, was impossible of realisation at Craig's Court. Consequently, he agitated for more suitable accommodation and, the time being ripe, he met with rapid success ; the new Museum in Jermyn Street was commenced in 1848 and opened by the Prince Consort on May 12, 1851, as the "Museum of Practical Geology, Government School of Mines and Science applied to the Arts".

Within the limitations set by the confined space and the complex functions of the new building, Pennethorne's design must be regarded as successful. Yet from the beginning, its scale was too small for its duties; room had to be found in a small house on the west side of the new build. ing for the Geological Survey staff and Mining Record Office; while on the east side, another house was occupied in part by the metallurgical laboratory.

It was here that De la Beche, 'President' of the new school, with the small but brilliant staff he had assembled, laid the foundations of what are to-day the Imperial College of Science and Technology and the Royal School of Mines at South Kensington. The first professors were, Lyon Playfair (chemistry); Edward Forbes (natural history applied to geology and the arts) ; T. Hunt (mechanical science, including some physics); J. Percy (metallurgy); Andrew C. Ramsay (geology); Warrington W. Smyth (mining and mineralogy). Hunt was also keeper of mining records, and Trenham Reeks was registrar of the School and curator of the Museum.

In 1853 there was some expansion of the scope of the School and its title became the "Metropolitan School of Science applied to Mining and the Arts"; then in 1859 the courses for the associateship were restricted to mining and metallurgy, with geology, and the title of the School reverted to the original one. In 1863 the School became the Royal School of Mines.

From the commencement, instruction had been given mainly by lectures, though practical work was done in metallurgy, chemistry and geology under restricted conditions. The demand for more laboratory teaching grew, with the result that the Departments of Chemistry, Physics and Biology were transferred to South Kensington, in what is now the Huxley Building; Geology, Metallurgy, Mining and Applied Mechanics followed later, but Percy clung to his old laboratory until 1880.

Besides being used for most of the School lectures, the theatre, capable of seating about six hundred, was employed for a series of evening
“Lectures to Working Men". These were delivered mostly by professors of the School, but included also some of the foremost scientific workers of the day. Every effort was made to limit admission to bona fide working men, but the lectures became so popular that there was keen competition for tickets from persons of all classes. After the transfer of some of the departments, the public lectures ceased to be given at Jermyn Street, but until the close of the last century, the theatre was in demand for the meetings of scientific societies; its demolition then permitted a much needed expansion for the exhibition and storage of specimens and models.

The duty of the Museum was, in the first place, to be the depository for material collected by the Geological Survey and for its display, along with the geological maps and models; but in order to function as a museum of practical geology, its field had to embrace all useful mineral substances. The exhibits of rocks and fossils were limited to those of the United Kingdom and were arranged in stratigraphical order; the minerals included specimens from all parts of the world and these were arranged in groups according to their bases and topographically, by far the most convenient system for public use. Along with the ores of metals were exhibits illustrating the mode of extraction and metallurgy, with examples of manufactured products.

The rapid growth of industrial application of the sciences soon made it impossible to keep pace with progress in the arts. The metallurgical exhibits ceased to be developed for lack of room, though the fine collection of porcelain and pottery had been allowed to expand to dimensions quite out of proportion to the rest of the scheme. Eventually these technological exhibits were dispersed to other museums, and the Jermyn Street display during the past thirty years has been confined to the practical aspects of geology and mineralogy.

From time to time various proposals had been made for the reorganisation of the Survey and Museum, but no decision was taken until the Museums Commission met in 1927; acting upon the Commission's recommendation, the Government agreed to the transfer to the site in Exhibition Road, proposed by the Bell Committee's Report of 1912, and the new building for the Museum of Practical Geology and offices of the Geological Survey was put in hand and completed by H.M. Office of Works in 1933 . This spacious building will afford the long-desired opportunity to arrange an exhibition on modern and more popular lines and with greater facilities for use as an educational instrument. Here De la Beche's ideal will attain its consummation, to the mutual advantage of all the related institutions at South Kensington.

The arduous work of removal and re-arrangement of the collections is in progress, and it is intended to synchronise the centenary celebration of the birth of the Geological Survey with the opening of the new museum in 1935. 